\title{
Investigation of Shear Stud Performance in Flat Plate Using Finite Element Analysis
}

\author{
T.S. Viswanathan ${ }^{1}$, G. Mohan Ganesh ${ }^{2} \&$ A.S. Santhi ${ }^{2}$ \\ ${ }^{1}$ Department of Civil Engineering, Velammal Engineering College, \\ Chennai 600066, Tamil Nadu, India \\ ${ }^{2}$ VIT University, Vellore 632007, Tamil Nadu, India \\ email: gmohanganesh@vit.ac.in
}

\begin{abstract}
Three types of shear stud arrangement, respectively featuring an orthogonal, a radial and a critical perimeter pattern, were evaluated numerically. A numerical investigation was conducted using the finite element software ABAQUS to evaluate their ability to resist punching shear in a flat plate. The finite element analysis here is an application of the nonlinear analysis of reinforced concrete structures using three-dimensional solid finite elements. The nonlinear characteristics of concrete were achieved by employing the concrete damaged plasticity model in the finite element program. Transverse shear stress was evaluated using finite element analysis in terms of shear stress distribution for flat plate with and without shear stud reinforcement. The model predicted that shear studs placed along the critical perimeter are more effective compared to orthogonal and radial patterns.
\end{abstract}

Keywords: flat plate; ABAQUS; shear reinforcement; punching shear strength; slab column connection; concrete damaged plasticity.

\section{Introduction}

A flat-plate system consists of reinforced concrete slabs of uniform thickness, without beams, drops or column capitals, which transfer loads directly to supporting columns. The main advantages of this system are reduced storey height and simple formwork, leading to fast construction and further reduction of material costs. Architecturally, the location of the columns and walls is not restricted by the location of any beams. Flat plate can be constructed as thin as $125 \mathrm{~mm}$ [1]. For these reasons, flat plate is widely used for multi-story structures. However, in flat-plate structures, the slab-column connection is subjected to a combination of high bending moments and high shear stresses, which can lead to brittle punching shear failure at a load that is well below its flexural strength. Punching shear capacity is influenced by thickness of slab, flexural reinforcement, grade of concrete, size of column, etc. Most building codes mention that provision of shear reinforcement will increase the punching shear capacity of the slab-column connection. The performance of many types of shear reinforcement, including vertical and inclined stirrups, shear studs,

Received May $17^{\text {th }}, 2013,1^{\text {st }}$ Revision January $30^{\text {th }} 2014,2^{\text {nd }}$ Revision April $1^{\text {st }}, 2014,3^{\text {rd }}$ Revision May $7^{\text {th }}$, 2014, Accepted for publication June $25^{\text {th }}, 2014$.

Copyright $(2014$ Published by ITB Journal Publisher, ISSN: 2337-5779, DOI: 10.5614/j.eng.technol.sci.2014.46.3.7 
bent-up bars, hooked bars, and welded wire fabrics, has been tested extensively in the last few decades. Among these, shear studs show the best performance in both punching shear resistance and ductility [2]. The critical section for punching shear is at a distance of $d / 2(d=$ effective depth $)$ from the face of the column. When the shear stress at the critical section exceeds the design value, shear reinforcement should be provided. Shear stresses should be investigated at successive sections from the support and shear reinforcement should be provided up to a section where shear stress does not exceed the allowable shear strength of the concrete.

The finite element method is a numerical technique widely used in the engineering field. With the advancement of the understanding of the material properties of concrete, various constitutive laws and failure criteria have been developed to model the behavior of concrete. Therefore, an increasing number of researchers are using finite element analysis to study the response of reinforced concrete structures. Finite element modeling of a flat-plate system requires that the punching shear failure of the slab column connections is reproduced properly. Such a simulation has been the focus of many numerical studies using various elements.

ABAQUS is a well-established commercial finite element code. Its constitutive models treat concrete as a continuous isotropic linearly elastic-plastic strainhardening fracture material. The software provides the capability of simulating damage using three crack models for reinforced concrete elements: (i) the smeared crack concrete model; (ii) the brittle crack concrete model; and (iii) the concrete damaged plasticity model. Out of these three models, the concrete damaged plasticity model was selected for the present study because this technique has the potential to represent complete inelastic behavior of concrete both in tension and in compression, including damaged characteristics. The concrete damaged plasticity model assumes that the two main failure mechanisms in concrete are tensile cracking and compression crushing.

\section{Research Significance}

Eurocode 2 and ACI codes recommend the arrangement of shear studs around the slab-column connection in orthogonal and radial patterns. In an orthogonal pattern, shear studs are placed parallel to the column edges, which will arrest crack propagation in the orthogonal direction. In a radial pattern, shear studs are arranged along radial lines. This will arrest crack propagation in the radial direction. A critical perimeter pattern is a combination of orthogonal and radial patterns that can arrest crack propagation in both directions. According to ACI 421.1R [3], the gap between two shear stud lines should not exceed a distance of $2 \mathrm{~d}$, which can be maintained with a critical perimeter pattern but is not 
feasible with the other two patterns. This paper examines the effectiveness of orthogonal, radial and critical perimeter patterns as shown in Figure 1.

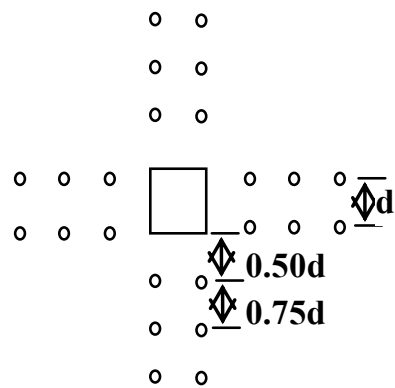

(a) Orthogonal pattern
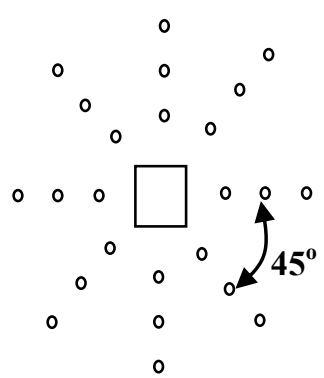

(b) Radial pattern

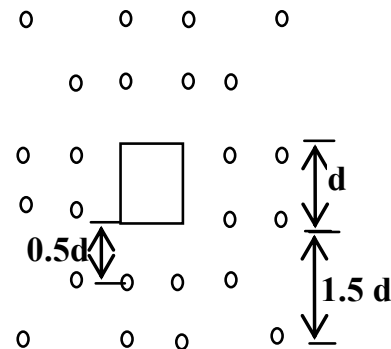

(c) Critical perimeter pattern

Figure 1 Arrangement of shear studs.

\section{$3 \quad$ Finite Element Model}

In order to incorporate the nonlinear behavior of the concrete, the concrete damaged plasticity model in ABAQUS was used. This provides a general capability for modeling concrete and other quasi-brittle materials in all types of structures (beams, trusses, shells, and solids). This model uses the concepts of isotropic damaged elasticity in combination with isotropic tensile and compressive plasticity to represent the inelastic behavior of concrete. This model is designed for applications in which the concrete is subjected to arbitrary loading conditions, including cyclic loading. The model takes into consideration the degradation of elastic stiffness induced by plastic straining both in tension

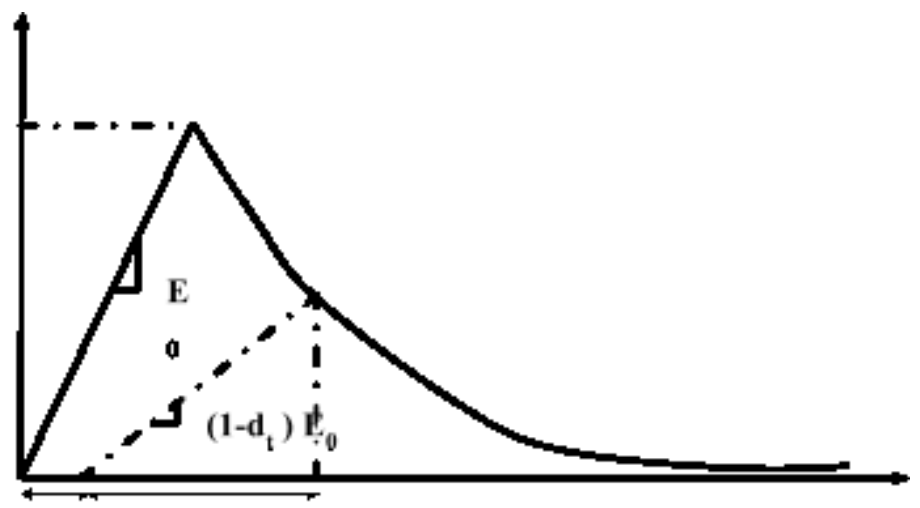

Figure 2 Response of concrete to uniaxial loading in tension. 
and compression. It also accounts for stiffness recovery effects under cyclic loading. The model is a continuum, plasticity-based damage model for concrete. It assumes that the main two failure mechanisms are tensile cracking and compressive crushing of the concrete material. The evolution of the yield (or failure) surface is controlled by two hardening variables linked to failure mechanisms under tension and compression loading. The response of concrete to uniaxial loading, both in tension and compression, are shown in Figures 2 and 3 (ABAQUS manual). Input parameters required for this model are plasticity, compression and tension, which are described below.

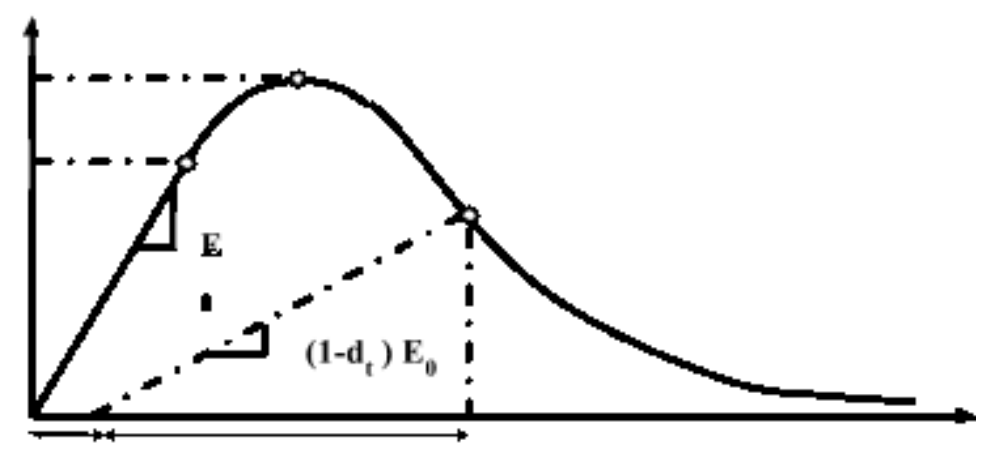

Figure 3 Response of concrete to uniaxial loading in compression.

\subsection{Plasticity Parameters}

There are five parameters that need to be defined to solve the Drucker-Prager plastic flow function and the yield function proposed by Lubliner, et al. [4]. To obtain exact values of the various parameters for the concrete damaged plasticity model, a uniaxial compression test, a uniaxial tension test, a biaxial failure in plane state of stress and triaxial test would have to be carried out for the material, but due to the lack of sufficient information, the default parameters in ABAQUS and the parameters proposed in other publications have been used. The parameters needed to describe the plastic properties of concrete are:

\subsubsection{Dilation Angle $\psi$}

The ratio of volume change to shear strain is called the dilation angle. In the Drucker-Prager formulation, the value of the dilation angle is to be determined for the element under biaxial compression at high confining pressures. According to Vermeer and de Borst [5], the typical dilation angle for concrete is $12^{\circ}$ and this value was used in this model. 


\subsubsection{Eccentricity}

This parameter is the rate at which the Drucker-Prager function approaches the asymptote. With an eccentricity tending to zero the plastic flow tends to a straight line. In further calculations, an eccentricity of 0.1 was used. This value is used to get a soft curvature of the potential flow and provides almost the same dilation angle for a wide range of confining pressure values.

\subsection{3 $\sigma_{\mathrm{co}} / \sigma_{\mathrm{bo}}$ Parameter}

This is the ratio of the initial equibiaxial compressive strength to the uniaxial compressive strength. This parameter is necessary to solve the yield function. The default value 1.16 was used in this model.

\subsubsection{Viscosity Parameter}

The viscosity parameter is required when a convergence problem is caused by softening behavior. As flat-plate models cause convergence difficulties, the viscosity parameter was assumed to be 0.05 .

\subsubsection{KcParameter}

The value of the $\mathrm{K}_{\mathrm{c}}$ parameter is to be determined considering the yield surface in the deviatory plane, as shown in Figure 4 (ABAQUS manual). $\mathrm{K}_{\mathrm{c}}$ is the ratio of the second stress invariant on the tensile stress meridian (T.M.) to the second stress invariant on the compressive stress meridian (C.M.). The value $2 / 3$ was used in the calculations.

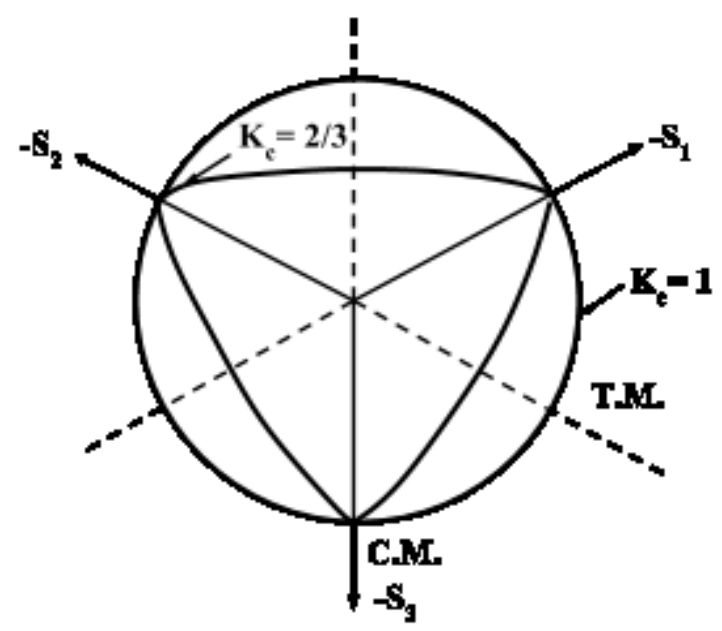

Figure 4 Yield surfaces in deviatory plane. 


\subsubsection{Compressive Behavior}

An accurate model of the compressive behavior is necessary for this analysis. Values of ultimate strength, yield strength and compression damage were taken from the ABAQUS verification manual, which assumes that the yield strength is $74 \%$ of the ultimate strength and the plastic strain at failure is $0.12 \%$

\subsubsection{Tensile Behavior}

The concrete damaged plasticity modelallows determination of post failure behavior in tension by defining strain, crack opening or fracture energy towards plastic tensile stress. These three options are related to one another and the choice of them depends on the knowledge of structural behavior and material. The input values required for tensile behavior were taken from the ABAQUS verification manual [6].

\section{$4 \quad$ Modeling of Flat Plate}

To analyze the effectiveness of different shear stud arrangements, four flat-plate slabs were modeled. Slab 1 was modeled without shear studs; slab 2 was

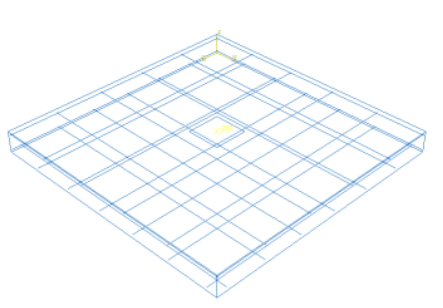

(a) Slab 1

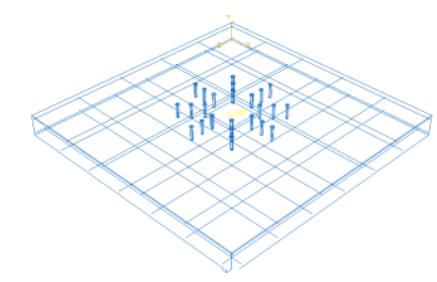

(c) Slab 3

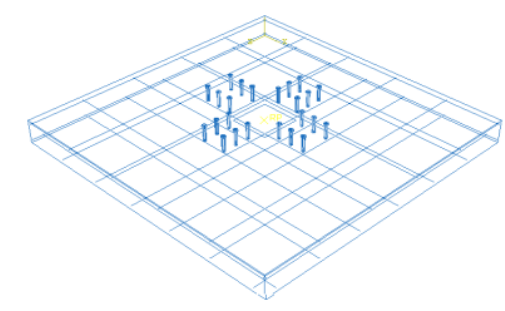

(b) Slab 2

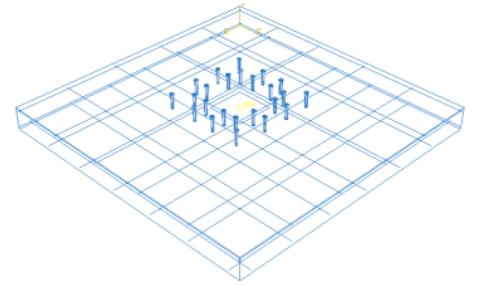

(d) Slab 4

Figure 5 Slab models.

modeled with shear studs in an orthogonal pattern; slab 3 was modeled with the studs in a radial pattern, and in slab 4 the studs were placed in a critical 
perimeter pattern as a matrix grid, as shown in Figure 5. The size, shape and elements of the flat-plate model selected for this study are similar to the ones used by H. Marzouk, et al. [2]. Slabs with a size of $1500 \mathrm{~mm} \times 1500 \mathrm{~mm} \times 125$ $\mathrm{mm}$ were modeled with 4107 eight node linear hexahedral elements (C3D8R) (Figure 6). Each element has eight corner nodes, and each node has three degrees of freedom (translation in the $\mathrm{X}, \mathrm{Y}$ and $\mathrm{Z}$ direction). The concrete is assumed to be homogeneous and isotropic.

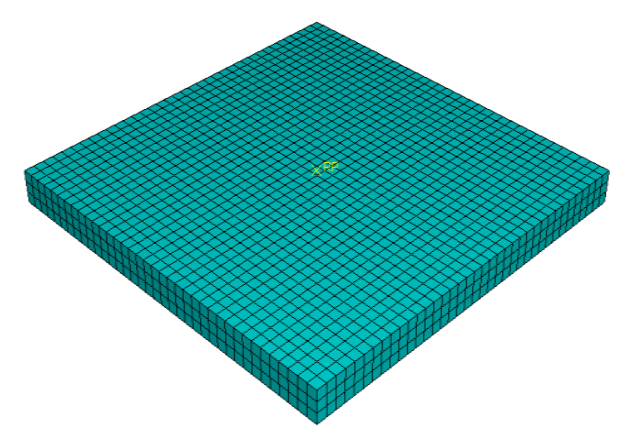

Figure 6 Finite Element Model of slab.

The slab is simply supported along the four sides and load is applied at a column stub area of $200 \mathrm{~mm} \times 200 \mathrm{~mm}$ (Figure 7). To avoid movement and rotation of the plane, two opposite corners are fixed [7]. The column stub is represented as a uniform load applied over an area $200 \mathrm{~mm}$ x $200 \mathrm{~mm}$ equivalent to the area of the stub, as is generally used in this kind of slab analysis.

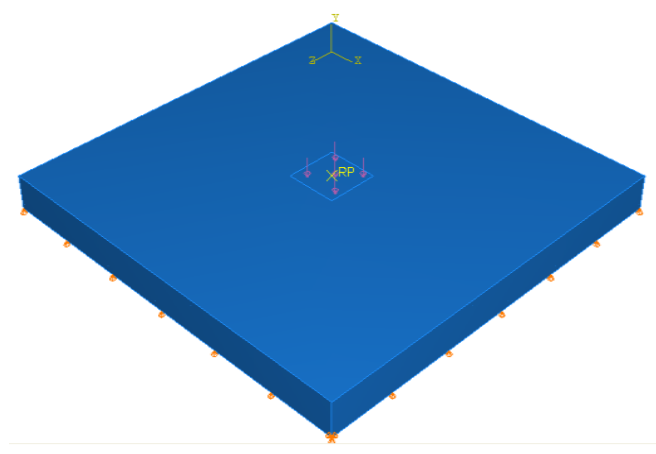

Figure 7 Flat-plate model.

Since the punching failure of the slab is being studied and not the joint stiffness as a whole, the assumption made is a reasonable one. Thus, the situation of stress concentration in the corner area, which causes difficulties in concrete 
modeling, is avoided. There are 7 and 6 pieces of $8 \mathrm{~mm} \phi$ bar at the bottom and top respectively in both directions. Flexural reinforcement was modeled with 20 linear truss elements (T3D2) and provided as per direct design method. Interaction between the concrete and the reinforcing steel was achieved by using an interaction module in which reinforcement is implemented as elements embedded in the concrete's host elements. Therefore, the assumed ideal bonding behavior between the concrete and the reinforcing steel has to be taken into account. A shear stud was modeled with 1308 four node tetrahedral elements (C3D4) (Figure 8)with an $8 \mathrm{~mm}$ diameter stem and a $24 \mathrm{~mm}$ head diameter, similar to the one used by Carl EriksBroms [8]. There are 24 pieces

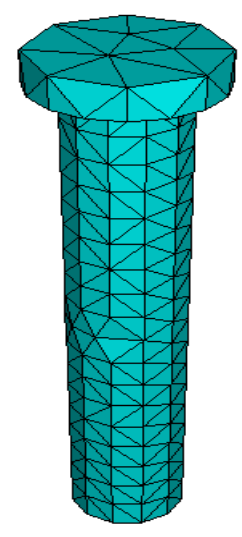

Figure 8 Finite element model of shear stud.

Table 1 Compressive Stress-Strain values for Concrete.

\begin{tabular}{cccc}
\hline $\begin{array}{c}\text { Compression Damage } \\
\text { Factor }\end{array}$ & Inelastic Strain & $\begin{array}{c}\text { Stress } \\
\left(\mathbf{N} / \mathbf{m m}^{\mathbf{2}}\right)\end{array}$ & $\begin{array}{c}\text { SI. } \\
\text { No. }\end{array}$ \\
\hline 0.000 & 0.0000 & 24.00 & 1 \\
0.129 & 0.0004 & 29.20 & 2 \\
0.242 & 0.0008 & 31.70 & 3 \\
0.341 & 0.0012 & 32.30 & 4 \\
0.426 & 0.0016 & 31.76 & 5 \\
0.501 & 0.0020 & 30.37 & 6 \\
0.566 & 0.0024 & 28.50 & 7 \\
0.714 & 0.0036 & 21.90 & 8 \\
0.824 & 0.0050 & 14.89 & 9 \\
0.969 & 0.0100 & 2.95 & 10 \\
\hline
\end{tabular}

of shear studs provided at a distance of $\mathrm{d} / 2$ from the face of the column and at an interval of $0.75 \mathrm{~d}$ for all three slabs. Many trials were carried out for mesh convergence to obtain reliable results with a finer mesh. The software evaluates 
all shear and normal stresses at each node, out of which shear stress S12 is considered in the comparison. Suitable material properties, compressive and tensile stress-strain behavior of concrete from the ABAQUS verification manual were used in this model (Table 1-3).

Table 2 Tensile Stress-Strain Values for Concrete.

\begin{tabular}{cccc}
\hline $\begin{array}{c}\text { Tensile Damage } \\
\text { Factor }\end{array}$ & $\begin{array}{c}\text { Cracking } \\
\text { Strain }\end{array}$ & $\begin{array}{c}\text { Stress } \\
\left(\mathbf{N} / \mathbf{m m}^{2}\right)\end{array}$ & $\begin{array}{c}\text { Sl. } \\
\text { No. }\end{array}$ \\
\hline 0.00 & 0.0000 & 1.780 & 1 \\
0.30 & 0.0001 & 1.450 & 2 \\
0.55 & 0.0003 & 1.113 & 3 \\
0.70 & 0.0004 & 0.960 & 4 \\
0.80 & 0.0005 & 0.800 & 5 \\
0.90 & 0.0008 & 0.536 & 6 \\
0.93 & 0.0010 & 0.359 & 7 \\
0.95 & 0.002 & 0.161 & 8 \\
\hline
\end{tabular}

Table 3 Material properties.

\begin{tabular}{cccc}
\hline $\begin{array}{c}\text { Poissons } \\
\text { ratio }\end{array}$ & Density & $\begin{array}{c}\text { Elastic modulus } \\
\text { (MPa) }\end{array}$ & Material \\
\hline 0.167 & $24 \mathrm{KN} / \mathrm{m}^{3}$ & 26480 & Concrete \\
0.300 & $7800 \mathrm{Kg} / \mathrm{m}^{3}$ & 200000 & Steel \\
\hline
\end{tabular}

\section{Comparison between FEM Results and Code Predictions}

The FEM results of the punching shear strength were compared with the predictions based on the equations specified in ACI-318M-08 [9], CEB-FIP MC 90 [10] and Eurocode 2 [11].

ACI $318 \mathrm{M}-08$ has the expression for the nominal shear strength of concrete given by

$$
V_{c}=0.33 \sqrt{f_{c}^{\prime}} b d
$$

where $\sqrt{f_{c}^{\prime}}$ should not exceed 8.3Mpa.

The variable $b$ is the perimeter of the critical section located at a distance of $0.5 d$ from the faces of the column.

The Eurocode 2 provisions are effectively identical to those of CEB-FIP MC 90 with the expression of the nominal shear strength of concrete given by 


$$
\mathrm{V}_{\mathrm{c}}=0.18\left[1+\sqrt{\frac{200}{\mathrm{~d}}}\right]\left[100 \rho \mathrm{f}_{\mathrm{ck}}\right]^{1 / 2} \mathrm{bd},
$$

where $b=4 c+\pi d$ and the term $200 / d$ should not exceed 1 .

The characteristic concrete cylinder strength $f_{c k}$ is limited to $50 \mathrm{MPa}$ and $\rho$ (flexural reinforcement ratio), calculated as $\rho=\sqrt{\rho_{x} \rho_{y}}$, is limited to a maximum of 0.02 .

Nominal shear strength with shear studs is given by,

$$
\begin{aligned}
& \mathrm{V}_{\mathrm{n} 1}=0.75 \mathrm{~V}_{\mathrm{c}}+1.5 \frac{\mathrm{A}_{\mathrm{v}} \mathrm{f}_{\mathrm{y}} \mathrm{d}}{\mathrm{s} \sin \alpha}(\mathrm{MC} 90, \mathrm{~s}<0.75 \mathrm{~d}) \\
& \mathrm{V}_{\mathrm{n} 1, \max }=0.5 * 0.6\left(1-\frac{\mathrm{f}_{\mathrm{c}}{ }^{\prime}}{250}\right) \mathrm{f}_{\mathrm{c}}^{\prime} 4 \mathrm{~cd} \\
& \mathrm{~V}_{\mathrm{n} 1}=0.75 \mathrm{~V}_{\mathrm{c}}+\frac{A_{\mathrm{v}} \mathrm{f}_{\mathrm{y}} \mathrm{d}}{\mathrm{s} \sin \alpha}(\text { ACI } 421.1 \mathrm{R}),
\end{aligned}
$$

where $\alpha$ is angle between shear reinforcement and plane of slab.

$$
\mathrm{V}_{\mathrm{n} 1 \text {, max }}=1.5 \mathrm{~V}_{\mathrm{c}} \text { if } 0.5 \mathrm{~d}<\mathrm{s} 1.5 \mathrm{~d}(\mathrm{ACI} 421.1 \mathrm{R})
$$

Nominal shear strength $V_{n 2}$ outside shear reinforcement is given by,

$$
\begin{aligned}
& \mathrm{V}_{\mathrm{n} 2}=0.18\left[1+\sqrt{\frac{200}{\mathrm{~d}}}\right]\left[100 \rho \mathrm{f}_{\mathrm{ck}}\right]^{\frac{1}{2}}(\mathrm{u}+4 \pi \mathrm{d}) \mathrm{d}(\mathrm{MC} 90) \\
& \mathrm{V}_{\mathrm{n} 2}=\frac{1}{6} \sqrt{\mathrm{f}_{\mathrm{c}}^{\prime}}(\mathrm{u}+\pi \mathrm{d}) \mathrm{d}(\text { ACI } 421.1 \mathrm{R}),
\end{aligned}
$$

\begin{tabular}{|c|c|c|c|c|c|c|c|}
\hline \multirow[t]{2}{*}{ S. No. } & \multirow{2}{*}{$\begin{array}{c}\text { Specimen } \\
\text { Code }\end{array}$} & \multicolumn{2}{|c|}{ Slab2 } & \multicolumn{2}{|c|}{ Slab3 } & \multicolumn{2}{|c|}{ Slab4 } \\
\hline & & $\begin{array}{c}\text { ACI } \\
421.1 \mathrm{R}\end{array}$ & MC 90 & $\begin{array}{c}\text { ACI } \\
421.1 R\end{array}$ & MC 90 & $\begin{array}{c}\mathrm{ACI} \\
421.1 \mathrm{R}\end{array}$ & MC 90 \\
\hline 1 & $\mathrm{~V}_{\mathrm{c}}, \mathrm{kN}$ & 181 & 79 & 181 & 79 & 181 & 79 \\
\hline 2 & $\mathrm{~V}_{\mathrm{n} 1}, \mathrm{kN}$ & 352 & 386 & 352 & 386 & 352 & 386 \\
\hline 3 & $\mathrm{~V}_{\mathrm{n} 1, \max }, \mathrm{kN}$ & 271 & 473 & 271 & 473 & 271 & 473 \\
\hline 4 & $\mathrm{~V}_{\mathrm{n} 2}, \mathrm{kN}$ & 192 & 235 & 166 & 212 & 168 & 214 \\
\hline 5 & $\mathrm{~V}_{\text {pred, }}, \mathrm{kN}$ & 271 & 386 & 271 & 386 & 271 & 386 \\
\hline 6 & $\mathrm{~V}_{\mathrm{FEM}} \mathrm{kN}$ & \multicolumn{2}{|c|}{255} & \multicolumn{2}{|c|}{276} & \multicolumn{2}{|c|}{281} \\
\hline 7 & $\mathrm{~V}_{\mathrm{FEM}}, / \mathrm{V}_{\text {pred }}$ & 0.94 & 0.66 & 1.01 & 0.72 & 1.03 & 0.73 \\
\hline
\end{tabular}

where $u$ is the perimeter of the outer most peripheral line ofthe shear reinforcement.

The FEM results are compared with the predictions according to ACI421.1R-99 and CEB-FIP Model Code1990 in Table 4.

Table 4 FEM results versus code predictions. 


\section{$6 \quad$ Results and Discussion}

The investigation of transverse shear stress around the slab-column connection has been carried out using finite element analysis because it is difficult to obtain this distribution and its associated parameters from experimental investigation. Results obtained from this model are reliable for three reasons: (i) the loaddeflection response of the flat-plate system (Figure 9) obtained from this model is similar to the one obtained by many experimental investigations by other researchers; (ii) the high shear-stress concentration in the top surface of the slab near the loading face $(0.5 \mathrm{~d}$ to $2 \mathrm{~d})$ matches with the critical section for shear mentioned by various building codes (Figure 10); and (iii) the truncated cone visualized in the plastic strain result of this model (Figure 11) resembles the formation of the punching cone caused by the diagonal cracking around the column.

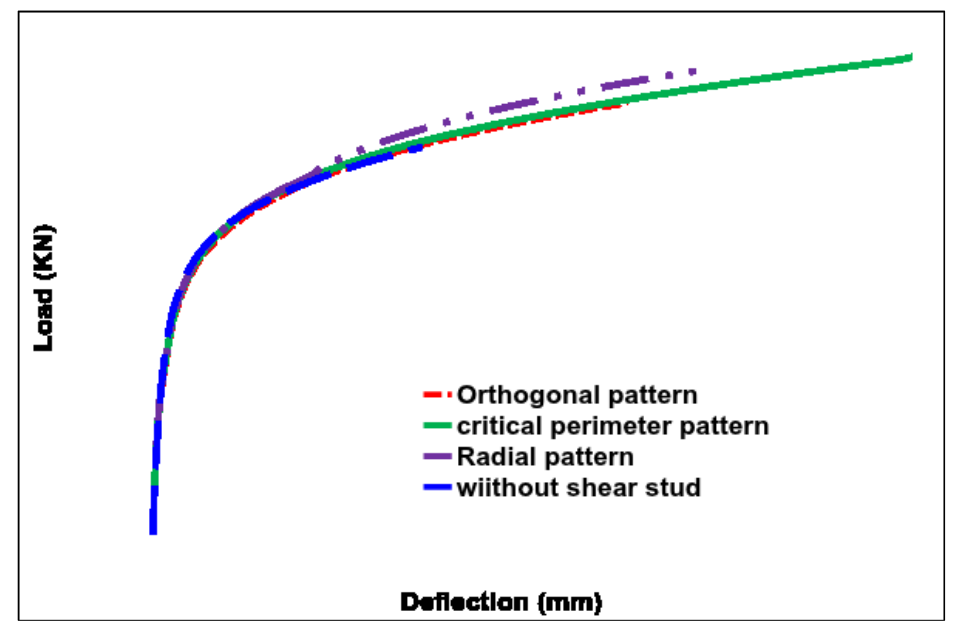

Figure 9 Load vs.deflection curve.

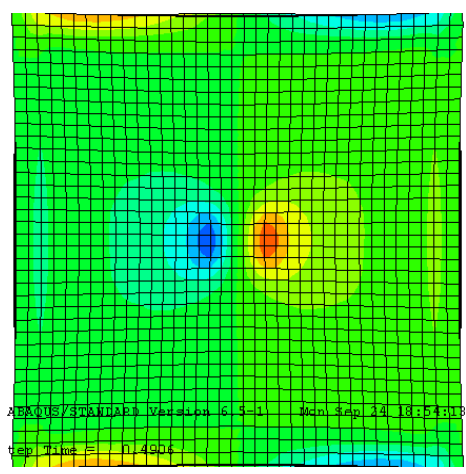

Figure 10 Shear stress concentration. 


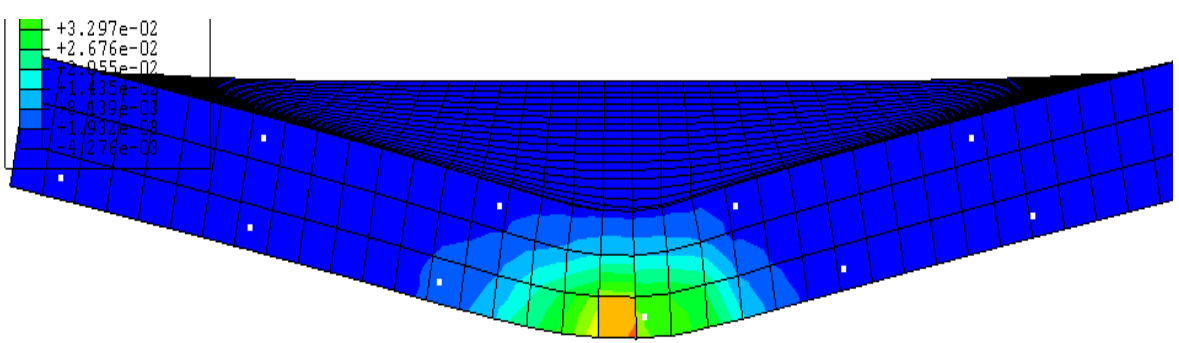

Figure 11 Crack pattern of punching shear failure.

In slab 1, a node that attained the maximum shear stress value was identified, along which seven nodes were selected from the face of the column to a distance of $2 \mathrm{~d}$. At these selected nodes, shear stress distribution in slab 1, slab 2, slab 3, and slab 4 was determined at an ultimate load of $228 \mathrm{kN}, 255 \mathrm{kN}, 276 \mathrm{kN}$ and $281 \mathrm{kN}$, respectively. From the graph (Figure 12) it is very clear that the shear stress value of the concrete for the slab with shear studs at most of the nodes was well below that of the slab without shear studs. Slab 3 and slab 4 showed very good performance against punching shear strength compared to slab 2.

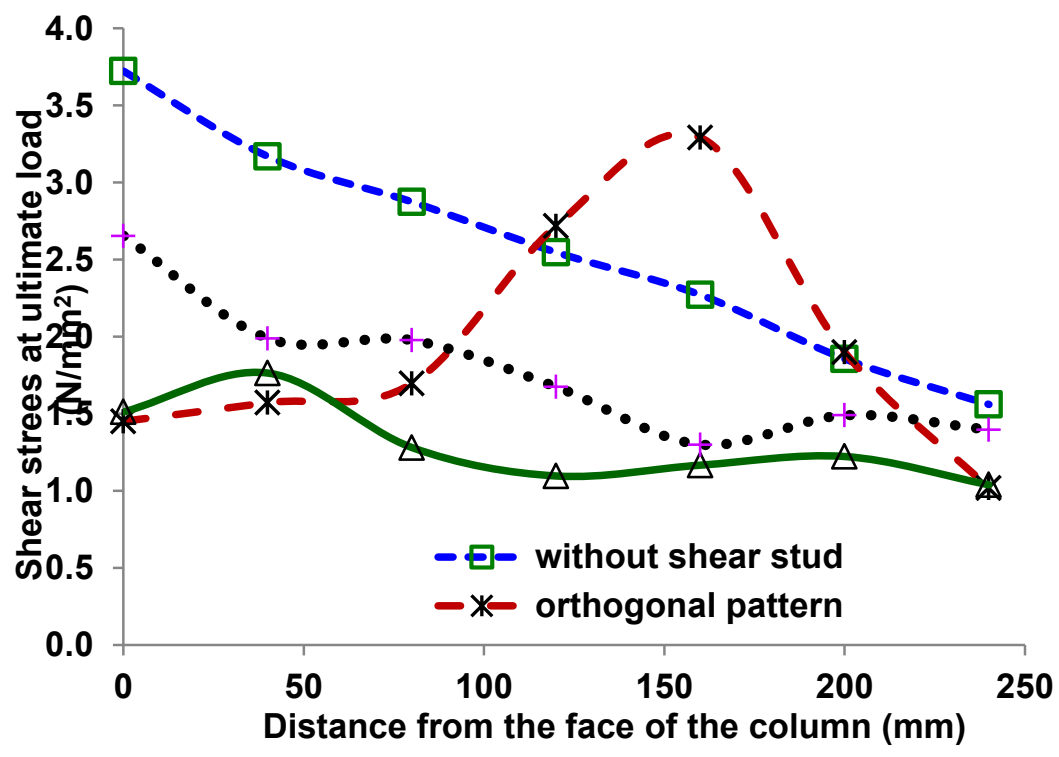

Figure 12 Shear stress distribution of concrete.

A comparison of maximum punching shear strength, ultimate shear stress, and maximum central deflection of all four slabs is shown in Table 5. The enhanced behavior observed in the critical perimeter pattern can be due to the fact that all 
studs are arranged in two rows that are within $1.5 \mathrm{~d}$ distance from the column face, whereas in the orthogonal and radial patterns, the studs are in three rows that are at a distance of up to $2 \mathrm{~d}$.

Table 5 Finite Element Analysis Results.

\begin{tabular}{ccccc}
\hline $\begin{array}{c}\text { Central } \\
\text { deflection }(\mathbf{m m})\end{array}$ & $\begin{array}{c}\text { Ultimate load } \\
(\mathbf{K N})\end{array}$ & $\begin{array}{c}\text { Ultimate shear } \\
\text { stress (MPa) }\end{array}$ & $\begin{array}{c}\text { Shear } \\
\text { reinforcement }\end{array}$ & Specimen \\
\hline 28.7 & 228 & 3.72 & None & Slab 1 \\
50.1 & 255 & 4.8 & $\begin{array}{c}\text { Orthogonal } \\
\text { pattern } \\
\text { Radial pattern }\end{array}$ & Slab 2 \\
54.39 & 276 & 3.66 & $\begin{array}{c}\text { Slab 3 } \\
\text { Critical perimeter } \\
\text { pattern }\end{array}$ & Slab 4 \\
79.4 & 281 & 5.95 & & \\
\hline
\end{tabular}

\section{$7 \quad$ Conclusions}

In this paper, a nonlinear analysis of flat-plate systems with three different shear stud arrangements was performed using the ABAQUS software program. Based on the numerical results, it can be concluded that away from the face of the column, shear stress reduces gradually. The punching shear strength is higher for the critical perimeter pattern than for the other patterns. The critical perimeter pattern and radial pattern show improved ductility characteristics compared to the orthogonal pattern. This model agrees well with ACI prediction compared to CEB-FIP MC 90 prediction.

\section{Nomenclature}

Total area of shear reinforcement on peripheral line around $=\mathrm{A}_{\mathrm{V}}$ column

Width of circular column

Effective depth of slab

$=\mathrm{C}$

Compression damage factor

$=\mathrm{D}$

Initial elastic stiffness

$=\mathrm{d}_{\mathrm{c}}$

Yield strength of reinforcing steel

$=\mathrm{E}_{0}$

Concrete compressive strength of cylinder

$=\mathrm{f}_{\mathrm{y}}$

$=\mathrm{f}_{\mathrm{c}}$ '

Spacing of stirrup

$=\mathrm{S}$

Nominal punching capacity of concrete without shear

$=\mathrm{V}_{\mathrm{c}}$

reinforcement

Predicted shear strength of slab; maximum of $\{[$ minimum of

$=\mathrm{V}_{\text {pred }}$

Row2 and Row3] and Row 4 \} of Table 4

Shear strength determined using finite element analysis

$=\mathrm{V}_{\mathrm{FEM}}$ 
Nominal punching capacity with shear reinforcement

$$
\begin{aligned}
& =\mathrm{V}_{\mathrm{n} 1} \\
& =\mathrm{V}_{\mathrm{n} 1 \text { max }} \\
& =V_{n 2} \\
& =\tilde{\varepsilon}_{\mathrm{t}} \mathrm{pl}^{\mathrm{pl}} \\
& =\tilde{\varepsilon}_{\mathrm{c}} \mathrm{pl}^{\mathrm{pl}} \\
& =\mathrm{d}_{\mathrm{t}} \\
& =\varepsilon_{\mathrm{t}}^{\mathrm{el}} \\
& =\varepsilon_{\mathrm{c}}^{\mathrm{el}} \\
& =\mathrm{P} \\
& =\rho_{\mathrm{x}} \\
& =\rho_{\mathrm{y}}
\end{aligned}
$$

\section{References}

[1] Plain and Reinforced Concrete-Code of Practice, IS 456:2000, Bureau of Indian Standards, New Delhi, India, 2000.

[2] Marzouk, H. \& Jiang, D., Finite Element Evaluation of Shear Enhancement of High Strength Concrete Plate, ACI Structural Journal, 93, pp. 667-673, 1996.

[3] Joint ACI-ASCE Committee 421, Shear Reinforcement for Slabs (ACI421.1R-99), American Concrete Institute, Farmington Hills, Michigan, USA, 1999.

[4] Lubliner, J., Oliver, J., Oller, S. \& Onate, E., A Plastic-Damage Model for Concrete, International Journal of Solids and Structures, 25(3), pp. 229-326, 1989.

[5] Vermeer, P.A. \& de Borst, R., Non-Associated for Soils, Concrete and Rock, Delft University of Technology, Heron, 1984.

[6] ABAQUS Manual, Example Problems, Verification Manual (Version 6.5), Dassault Systèmes Simulia Corp., Providence, RI, USA, 2005.

[7] Xiao, R.Y. \& Flaherty., T.O., Finite-Element Analysis of Tested Concrete Connections, Computers and Structures, 78, pp. 247-255, 2000.

[8] Broms, C.E., Ductility of Flat Plates: Comparison of Shear Reinforcement Systems, ACI Structural Journal, 104(6), pp. 703-711, 2007.

[9] ACI Committee 318, Building Code Requirements for Structural Concrete (ACI 318M-05) and Commentary, American Concrete Institute, Farmington Hills, Michigan, USA, 2005.

[10] Joint CEB-FIP Committee, Model Code 90, CEB Bulletin, No. 213-214, Lausanne, Switzerland, pp. 437, 1993.

[11] Eurocode 2, Design of Concrete Structures, Part 1-1: General Rules and Rules for Buildings, European Standards, CEN, EN1992-1-1, Brussels, Belgium, pp. 225, 2004. 